
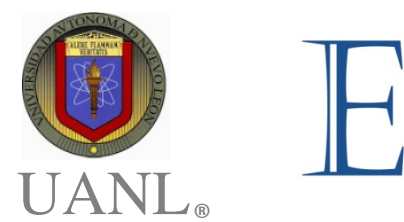

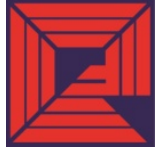

Facultad de

ensayos.uanl.mx

\title{
Regional Input-Output Matrices and an Application to Analyze a Manufacturing Export Shock in Mexico
}

\author{
Matrices insumo producto regionales y una aplicación para \\ analizar impactos de las exportaciones manufactureras en \\ México
}

\author{
Jorge Alvarado*§ \\ Miroslava Quiroga* \\ Leonardo Torre* \\ Daniel Chiquiar
}

\begin{tabular}{|c|c|}
\hline Article information & Abstract \\
\hline $\begin{array}{l}\text { Received: } \\
11 \text { november } 2017\end{array}$ & $\begin{array}{l}\text { Based on the national Input-Output Matrix (IOM) } 2012 \\
\text { calculated by INEGI, we estimate with the Flegg approach } \\
\text { four regional Input-Output Matrices (RIOMs) using Banco }\end{array}$ \\
\hline $\begin{array}{l}\text { Accepted: } \\
4 \text { october } 2019\end{array}$ & $\begin{array}{l}\text { de México's regionalization (Northern, North-Central, } \\
\text { Central and Southern). These RIOMs are employed to }\end{array}$ \\
\hline $\begin{array}{l}\text { JEL Classification: } \\
\text { O14; R11; R12; R15 }\end{array}$ & $\begin{array}{l}\text { evaluate the impact on regional gross output, value added } \\
\text { and employment from a } 10,000 \text { million dollar shock on } \\
\text { Mexican manufacturing exports. The results show that the }\end{array}$ \\
\hline $\begin{array}{l}\text { Keywords: } \\
\text { Input-Output Model; } \\
\text { Regional Analysis; } \\
\text { Multiplier Effects; } \\
\text { Exports }\end{array}$ & $\begin{array}{l}\text { effects on the absolute values of gross output, value added } \\
\text { and employment in the North are clearly larger than those } \\
\text { estimated for the other regions. Another finding is that the } \\
\text { total effects of the regional shocks tend to concentrate in } \\
\text { the manufacturing sector, with the highest concentration } \\
\text { observed in the North, and the lowest in the South. It is } \\
\text { also shown that the North is, by far, the region } \\
\text { experiencing the greatest change in its value added relative } \\
\text { to GDP, followed by the North Central, the Central and the } \\
\text { South. The results suggest a strong linkage between the } \\
\text { manufacturing sector and tertiary activities, particularly } \\
\text { commerce and services in the central regions, as well as } \\
\text { between manufacturing and oil and gas extraction in the } \\
\text { South. }\end{array}$ \\
\hline
\end{tabular}

$\S$ Email: jorge.alvarado@banxico.org.mx

* Banco de México.

ISSN Electrónico: 2448-8402 | ISSN Impreso: 1870-221X | (C2019 Los autores @) () 


\begin{tabular}{|c|c|}
\hline $\begin{array}{l}\text { Información del } \\
\text { artículo }\end{array}$ & Resumen \\
\hline Recibido: & \multirow{7}{*}{$\begin{array}{l}\text { A partir de la Matriz de Insumo-Producto nacional (MIP) } \\
2012 \text {, calculada por el INEGI, estimamos cuatro Matrices } \\
\text { de Insumo-Producto regionales (MIPRs) utilizando el } \\
\text { enfoque de Flegg. Estas matrices se emplean para evaluar } \\
\text { el impacto en producción bruta, valor agregado y empleo } \\
\text { en el nivel regional de un choque de } 10,000 \text { millones de } \\
\text { dlares, en las exportaciones manufactureras mexicanas. } \\
\text { Los resultados muestran que los efectos sobre los valores } \\
\text { absolutos de la producción bruta, el valor agregado y el } \\
\text { empleo en el Norte son significativamente mayores que los } \\
\text { estimados para las otras regiones. Se observa también que } \\
\text { los efectos totales de los choques regionales tienden a } \\
\text { concentrarse en el sector manufacturero, y que la mayor } \\
\text { concentración se encuentra en el Norte, y la más baja, en } \\
\text { el Sur. El Norte es también la región con el mayor cambio } \\
\text { en valor agregado como proporción del PIB, seguida por } \\
\text { la región Centro Norte, Centro y Sur. Sin embargo, los } \\
\text { efectos indirectos tienden a ser mayores en regiones } \\
\text { alejadas de la frontera con Estados Unidos. Así, los } \\
\text { resultados sugieren un fuerte vínculo entre el sector } \\
\text { manufacturero y las actividades terciarias, en particular, el } \\
\text { comercio y los servicios en las regiones centrales, y en la } \\
\text { fabricación y la extracción de petróleo y gas en el Sur. }\end{array}$} \\
\hline 11 noviembre 2017 & \\
\hline Aceptado: & \\
\hline 4 octubre 2019 & \\
\hline $\begin{array}{l}\text { Clasificación JEL: } \\
\text { R11; R12; R15 }\end{array}$ & \\
\hline $\begin{array}{l}\text { Palabras clave: } \\
\text { Modelo insumo } \\
\text { producto; Análisis } \\
\text { regional; Efecto } \\
\text { multiplicador; }\end{array}$ & \\
\hline & \\
\hline
\end{tabular}

Agradecimientos: Los autores agradecen los comentarios de Joana Chapa, Juan Carlos Chávez, Alejandrina Salcedo, Daniel Sámano, dos dictaminadores anónimos y a los participantes del $4^{\circ}$ Congreso Anual de Economía y Políticas Públicas en la Universidad Iberoamericana en la Ciudad de México. Los puntos de vista y conclusiones en este trabajo son responsabilidad exclusiva de los autores y no necesariamente reflejan los del Banco de México. Los errores restantes son responsabilidad de los autores.

\section{Introduction}

This paper estimates the direct and indirect effects that an exogenous shock to the manufacturing exporting sector can have on other sectors of economic activity at the regional level in Mexico. Positive shocks that originate in a particular manufacturing sector can have spill-over effects on other manufacturing sectors and on other activities-such as services or construction - via input-output linkages. To identify these effects, this paper extends traditional input-output matrix (IOM) analysis to obtain regional input-output matrices (RIOMs), which can be useful tools to characterize the regional heterogeneity in the organization of economic activity within a country. An IOM summarizes information regarding the economy's productive structure useful to evaluate the aggregate impact on the entire economic system produced by exogenous shocks that initially originate within a particular activity. The estimation of IOMs at the regional level allows for a richer characterization of the aggregate effects from the exogenous shocks as 
we may identify the differential spill-over effects that these shocks may have across regions within the same country.

Previous work has found that the regional impact of trade liberalization may be very heterogeneous. For example, Chiquiar (2005) and Cosar and Fajgelbaum (2016) study the regional impact of external economic integration and find that specialization patterns (i.e. sectoral composition) can lead to uneven effects of international trade. Similarly, authors, Dorn and Hanson (2013) find differential effects of import competition from China in local labor markets in the U.S. In a related paper, Chiquiar et al. (2014) also find heterogenous effects of trade shocks-such as the enactment of NAFTA or the entry of China into the WTO- - on Mexican labor markets. This paper focuses on a particular channel that can exacerbate or dampen the differential responses to an exogenous export shock at the regional level, and that can be relevant to explain heterogeneous regional effects of external shocks. In particular, even if the first order effect of an exogenous shock on exports for a particular region depends on its export orientation, regions in which sectors are more interconnected will benefit greater from the same shock relative to those with weaker sectoral links. This implies that heterogeneous effects can arise not only from a region's export capability, but also from its underlying microeconomic structure in terms of how economic activity is organized. Indeed, Acemoglu et al. (2012) and Foerster et al. (2011) have emphasized the role of intersectoral linkages as an amplification mechanism that accounts for a substantial amount of aggregate fluctuations. Moreover, Caliendo et al. (2016) argue that intersectoral and interregional linkages are keys to understanding the response of the aggregate economy to micro-level shocks.

Methodological advances, the availability of new and reliable data, and the development of more powerful and easy-to operate computational tools have made IOM analysis and its extension to RIOMs a tool that can be effectively implemented to further our understanding of the organization of economic activity and its consequences for aggregate outcomes. This paper uses the methodology in Alvarado et al. (2016) in order to estimate RIOMs for Mexico. In particular, RIOMs are estimated for the regionalization of the Mexican economy used in the Reporte Sobre las Economías Regionales of Banco de México, which divides Mexico into four economic regions: North, NorthCenter, Center, and South. ${ }^{1}$

\footnotetext{
${ }^{1} \mathrm{We}$ recognize that it is not a possible to determine the optimal regionalization of a country. In fact, in the case of Mexico other researchers have already estimated RIOMs defining the regions differently to ours. See, for instance, Callicó et al. (2000) for the Western region (Colima, Jalisco, Michoacán y Nayarit); Ayala y Chapa (2007) for the North-East (Nuevo León, Coahuila y Tamaulipas); and Dávila (2015), who compiles estimations of RIOMs for seven regions obtained by different authors. There are also some estimations of RIOMs at
} 
The main result of this paper deals with the heterogeneous regional impact of a shock to manufacturing exports on gross output, value added, and employment. For instance, a positive shock to manufacturing exports will naturally benefit the Northern region more due to its export orientation relative to other regions in Mexico. However, the RIOM analysis allows us to uncover that there is substantial regional heterogeneity in the indirect effects that arise from this external shock. In terms of the impact on gross output, it is seen that the indirect effect is largest in the South, where it accounts for 29 percent of the total effect, while the indirect effect is smallest in the North, where it accounts for 16 percent of the total effect. This result in itself may be surprising, because the North is the most industrially developed and export oriented region in the country, while the South has a less developed industrial structure and is more closed off to international trade. It is also interesting to note that in terms of gross output, the indirect effects are concentrated in service sectors such as transportation and administrative and support services. For value added the patterns are roughly the same as those for gross output, with the notable exception that, in this case, indirect effects play a larger role in accounting for the total regional effect. Regarding employment, the most notable result is that both the Northern and Southern regions register the largest direct effects to a shock in manufacturing exports. This stands in contrast to the results for gross output and valued added where the South always registered the smallest direct effect.

The paper is organized as follows: Section II presents the basic theoretical framework to construct regional input-output matrices; Section III describes the estimation of RIOMs for the Mexican case. Section IV uses the estimates of section III to estimate the impact of a shock to Mexican manufacturing on gross output, value added and employment; Section V concludes.

\section{Methodology}

\subsection{Derivation of the National Input-Output Matrix (IOM)}

The basic approaches to estimate a RIOM with indirect methods are invariably based on a national IOM. Once the latter has been obtained, its elements are transformed in accordance with the chosen methodology, as well as on different criteria related to the distinctive features of the region for which a RIOM is constructed.

the state level. Some examples are Fuentes (2005) for Baja California; Valdez (2004) for Tamaulipas; Dávila (2002) for Coahuila; and Chapa and Rangel (2010) and RodríguezOreggia (1995) for Nuevo León. 
The basic procedure to construct a national IOM starts by assuming that the gross output of an economy with " $n$ " sectors in one period can be represented as follows ${ }^{1}$ :

$$
\mathbf{x}=\mathbf{Z i}+\mathbf{f}
$$

where $\mathbf{x}$ is a ( $\mathrm{n} \times 1)$ vector of gross outputs; $\mathbf{Z}$ is a ( $\mathrm{x} \mathbf{n})$ matrix of (intermediate) sales to other productive sectors (with each of its elements given by $\left.z_{i j}\right)$; $\mathbf{f}$ is a (n x 1) vector of the final demands; and " $\boldsymbol{i}$ " represents a column vector of 1 's of dimension $(1 \times n)$.

In the input-output approach, the fundamental assumption is that the flow of goods and services of any given sector " $i$ " demanded by sector " $j$ " (i.e, the $z_{i j}$ elements of the $\mathbf{Z}$ matrix) depends exclusively on the total production of " $j$ " $\left(x_{j}\right)$, where this relation is expressed as follows:

$$
a_{i j}=\frac{z_{i j}}{x_{j}}
$$

Based on this definition, notice that:

$$
z_{i j}=a_{i j} x_{j}
$$

where $a_{i j}$ is a coefficient that captures, for sector " $j$ ", a fixed relation between the level of production of " $j$ " and the level of input " $i$ " used to obtain the referred production. These coefficients are called "fixed technical coefficients", implying that all productive sectors have Leontief production functions and, therefore, that all productive sectors have constant returns to scale. $^{2}$ Then (1) can be expressed as:

$$
\mathbf{x}=\mathbf{A x}-\mathbf{f}
$$

\footnotetext{
${ }^{1}$ Sections II.1 and II.2 are based on Miller and Blair (2009). In the discussion that follows, the variables are supposed to be measured in constant pesos of 2012. The approach can also be consulted in Leontief (1986).

${ }^{2}$ It should be noted that the input-output approach is usually employed to analyze short run impacts, which is why the assumption that fixed coefficient technology turns out to be adequate in the context of the analysis to be presented in section IV.
} 
Finally, solving for $\mathbf{x}$ :

$$
\begin{gathered}
\mathbf{X}=(\mathbf{I}-\mathbf{A})^{-\mathbf{1}} \mathbf{f} \\
\mathbf{X}=\mathbf{L f}
\end{gathered}
$$

where $\mathbf{L}=(\mathbf{I}-\mathbf{A})^{-1}$.

$\mathbf{L}$ is known as the "Leontief inverse matrix", or "matrix of total requirements", which its elements depend on $a_{i j}$. This matrix allows us to identify the impact of exogenous shocks on gross output by means of the so-called multiplier effects, and in which we are interested for the purposes of impact analysis. These multiplier effects are classified into direct (the effect on the economic sector that receives the exogenous shock), and indirect (the effect generated by the affected sector on other sectors of the economy it interacts with); while their sum is known as total multiplier. ${ }^{3}$ The intuition behind these multipliers is that when a sector experiences, for instance, a positive exogenous shock, it leads to greater productive activity in the same sector (a direct effect), as a result there is higher demand for intermediate inputs from other sectors of the economy involved in the productive process (an indirect effect), and so on. This process continues in a way that the economy's production grows more compared to the initial impact. This generates greater value added, and more employment in the economy. ${ }^{4}$

To obtain the coefficients $a_{i j}$ and, therefore, the IOM in Mexico's case, we rely on INEGI's IOMs estimates of 2012. The result generated from the RIOMs for Mexico, based on such IOM, is presented in the following section.

\subsection{Estimation of a RIOM}

The main goal of this paper is to construct RIOMs for Mexico. The literature on the subject indicates that the construction of a RIOM can be carried out using "direct methods", that is, methods that require statistical data obtained from surveys, just like a national IOM is constructed. ${ }^{5}$

\footnotetext{
${ }^{3}$ In the literature on input-output matrices, "direct" and "indirect" multipliers are called "type I multipliers". When the "induced" impacts on the variables of interest are considered, the multipliers are called "type II multipliers". See Bess and Ambargis (2011).

${ }^{4}$ For the formal derivation of gross output, value added and employment multipliers, see Appendix 1 in Alvarado et al. (2017).

${ }^{5}$ On this approach, see Isard (1951) and Leontief (1953). Clearly, this approach implied high monetary and time costs, derived from capturing and processing statistical data. Still, in the 70s alternative techniques to construct RIOMs started to be developed, reducing their costs and presenting results with a reasonable degree of reliability. In this sense, technological developments in the field of data processing have been fundamental for the progress in the RIOMs estimation techniques.
} 
Alternatively, RIOMs can also be generated using "synthetic approaches", that is, using indirect and semi-direct methods (also known as hybrid methods), which help transform information available at the aggregate level to information at the regional level. ${ }^{6}$ The essence of these methods lies in adjusting the elements of an IOM to obtain components of a RIOM. Thus, in all cases there is an IOM as a starting point.

A practical problem with indirect methods, however, is that in order to convert technical coefficients from the national to the regional level, there is a set of different alternatives, which depend on the application of the so-called Location Quotients (LQ). A LQ is an analytical statistic that measures a region's industrial specialization relative to the nation, which is computed as an industry's share of a regional total for some economic variable divided by the industry's share of the value for the same statistic at the national level and for which there are various alternative methodologies to compute them. ${ }^{7}$

Given these alternatives, different studies have focused on evaluating the performance of the different LQs to construct RIOMs. Such evaluations compared the RIOMs estimated with "direct" methods against those obtained with "indirect" methods, and concluded that the best performance was observed using the Flegg method (FLQ) ${ }^{8}$ Therefore, the Flegg approach will be used in this paper to estimate the regional technical coefficients requited to obtain the RIOM. ${ }^{9}$

It should be stressed that the only economic series required for the estimation of Flegg's coefficients (FLQij) is states' GDP (which is the one used to calculate regional GDP) and national GDP per sector, which in Mexico is

\footnotetext{
${ }^{6}$ Hybrid models of matrices' regionalization, as implied by their name, are a combination of indirect methods that use data from surveys on productive activity and even expert opinions (see Lahr, 1993).

7 Among the LQs used to transform national quotients to regional quotients we find the simple location quotient (SLQ), the cross-industry quotient (CLQ), Round's semilogarithmic location quotient (RLQ), the symmetric cross-industry location quotient (SCILQ), Flegg's location quotient (FLQ) and the augmented Flegg's location quotient (AFLQ) (Round, 1983; Flegg et al. 1995; Tohmo, 2004).

8 The exercises were carried out with data from the U.S. and some European countries, because they have more available resources to construct the IOM with "direct" methods. Bonfiglio and Chelli (2008), for instance, performed Monte Carlo simulations and concluded that FLQ and AFLQ are better at reproducing the real values of RIOMs. Subsequently, Flegg and Tohmo (2013), performed a new evaluation of the existing methodologies by taking advantage of 20 regional matrices for Finland, and estimated them using "direct" methods, and compared the technical coefficients obtained with different "indirect" methods with the "true" technical coefficients (i.e., those derived from the regional matrices, which in turn were obtained with "direct methods"). However, since the publication of Flegg and Tohmo (2013), the estimation of MIPRs has essentially followed their approach. See Dávila (2015). ${ }^{9}$ For a detailed discussion of the Flegg method, see Alvarado et al. (2017).
} 
provided by INEGI. The following section describes in detail how the rest of the necessary components to construct a RIOM are obtained.

\section{An Estimation of a RIOM for Mexico}

To construct a RIOM and use it to evaluate the possible effects of different exogenous shocks on the economic activity of any given region, the following information is required:

i) Obtain an IOM at the national level, which will be used to estimate data at the regional level.

ii) Construct a regional matrix of intermediate goods' consumption $\left(\mathrm{Z}^{\mathrm{R}}\right)$ using the regional technical coefficients $\left(a_{i j}^{R}\right)$ based on Flegg's approach.

iii) Obtain, by sector and region, the components of final demand $\left(F_{j}^{R}\right)$, that is, private consumption $\left(C_{j}^{R}\right)$, investment $\left(I_{j}^{R}\right)$, government spending $\left(G_{j}^{R}\right)$, exports $\left(E X P_{j}^{R}\right)$, value added $\left(V_{j}^{R}\right)$, and imports $\left(M_{j}^{R}\right)$; as well as the components of the payment sectors, namely, taxes $\left(T_{j}^{R}\right)$, wages $\left(R E M_{j}^{R}\right)$, and the payment of capital $\left(E B O_{j}^{R}\right)$.

Regarding the first point, as was mentioned before, INEGI provides estimations of the IOMs at the national level. In particular, as part of Mexico's National Accounts System, the Institute has published IOMs for 2003, 2008 and 2012. This paper uses the $2012 \mathrm{IOM}$, as it is the most recent one. ${ }^{10}$

It should be noted that in deriving the RIOMs, a disaggregation level of 31 subsectors was used in accordance with the North American Industry Classification System (NAICS), which implies working a three-digit disaggregation level. ${ }^{11}$ The reason to operate at this disaggregation level has to do with data availability at the state level, which is needed to construct some required variables at the regional level. On the other hand, it should be clarified that for some variables there is indeed information by state and economic

\footnotetext{
${ }^{10}$ The national IOMs of 2003 and 2008 are based on representative surveys of productive activity as well as on economic censuses (a direct method). Meanwhile, the 2012 IOM was obtained after updating the 2008 IOM with the indirect RAS method (Ratio Allocation System). It is noteworthy that the RAS method is a process of iterative adjustments in which the columns (purchases) and the lines (sales) of an IOM are forced to successively sum total values of the observed new levels of activity, taking as a reference point the structure of purchases and sales of an IOM derived from the direct method (an original matrix). The process of iterative adjustment consists in multiplying each cell of the original matrix by a given proportion between the total of the new observed value and the total of the original value, a process that is repeated until the differences between the sum of columns and lines with respect to the corresponding observed values tend to zero. For an example of this approach, see Lynch (1986), Toh (1998) and Trinh and Viet-Pong (2013).

${ }^{11}$ Appendix 1 presents the 31 subsectors considered by the NAICS.
} 
sectors, among them, Gross Domestic Product, obtained from Mexico's System of National Accounts; Wages, obtained from the National Survey of Occupation and Employment (ENOE, for its acronym in Spanish); and Exports, obtained from statistics of the external sector, released by INEGI. All of these variables at the state level will be the basis to obtain our regional level data.

Having detailed the above, we now proceed to discuss how to construct the regional matrix of intermediate goods' consumption $\left(\mathrm{Z}^{\wedge} \mathrm{R}\right)$, as well as the components of final demand and payment sectors, for which there is no disaggregated data. As it will be seen below, it will be in the construction of some of these components that the Flegg quotients will enter into play.

\subsection{Construction of the Regional Matrix of Intermediate Goods' Consumption $\left(Z^{R}\right)$}

The regional intermediate consumption of sector " $\mathrm{j}$ " that stems from sector " $\mathrm{i}$ " $\left(Z_{i j}^{R}\right)$ is obtained based on the following definition:

$$
Z_{i j}^{R}=a_{i j}^{R} * X_{j}^{R}
$$

where $X_{j}^{R}$ is the regional gross output of good " $\mathrm{j}$ ” and $a_{i j}^{R}$ is the regional technical coefficient.

Out of these two components, only $a_{i j}^{R}$ is available, which compels us to estimate $X_{j}^{R}$. To do so, let us keep in mind that the regional gross output of sector “ $\mathrm{j}$ ” $\left(X_{j}^{R}\right)$ is defined as:

$$
X_{j}^{R}=V_{j}^{R}+Z T_{j}^{R}+M_{j}^{R}+T_{j}^{R}
$$

where $V_{j}^{R}$ is the regional gross value added; $Z T_{j}^{R}$ is the total regional demand for intermediate goods; $M_{j}^{R}$ are regional imports; and $T_{j}^{R}$ are payments of regional taxes.

Given that there is no information at the state level for $M_{j}^{R}$ and $T_{j}^{R}$, they are estimated, as a result, as follows:

$$
M_{j}^{R}=m_{j}^{N} X_{j}^{R}
$$




$$
T_{j}^{R}=t_{j}^{N} X_{j}^{R}
$$

where it is assumed, on the one hand, that the national and regional average propensity to import are also equal $\left(m_{j}^{N}=m_{j}^{R}\right)$; and, on the other hand, that the effective national and regional tax rates are equal $\left(t_{j}^{N}=t_{j}^{R}\right)$. These two last assumptions are used, given that there is only information available on $m_{j}^{N}$ and $t_{j}^{N}$.

Based on the above definitions, expression (7) becomes ${ }^{12}$ :

$$
X_{j}^{R}=V_{j}^{R}+\left(\sum_{i=1}^{n} a_{i j}^{N} X_{j}^{R}\right)+\left(m_{j}^{N} X_{j}^{R}\right)+\left(t_{j}^{N} X_{j}^{R}\right)
$$

Finally, solving for $X_{j}^{R}$ :

$$
\begin{gathered}
X_{j}^{R}=V_{j}^{R}+\left(\sum_{i=1}^{n} a_{i j}^{N} X_{j}^{R}\right)+\left(m_{j}^{R} X_{j}^{R}\right)+\left(t_{j}^{R} X_{j}^{R}\right) \\
X_{j}^{R}\left(1-\sum_{i=1}^{n} a_{i j}^{N}-m_{j}^{R}-t_{j}^{R}\right)=V_{j}^{R} \\
X_{j}^{R}=\frac{V_{j}^{R}}{\left(1-\sum_{i=1}^{n} a_{i j}^{N}-m_{j}^{R}-t_{j}^{R}\right)}
\end{gathered}
$$

Thus, the gross output of sector " $\mathrm{j}$ ” in region " $\mathrm{R}$ " $\left(X_{j}^{R}\right)$ can be estimated with the formula referred above, as it contains the numerator $V_{j}^{R}$, that is, the value of the regional GDP of economic sector " $\mathrm{j}$ ", and for which there is information; and in the denominator there is a series of parameters that are regional technical coefficients $\left(a_{i j}^{R}\right)$, the region's average propensity to import $\left(m_{j}^{R}\right)$ and the regional effective tax rate $\left(t_{j}^{R}\right)$, for which there are also estimates. When the components of regional gross output $\left(X_{j}^{R}\right)$ and regional technical coefficients $\left(a_{i j}^{R}\right)$ are available, it is possible to estimate the following for each sector " $\mathrm{j}$ ":

$$
Z_{i j}^{R}=a_{i j}^{R} * X_{j}^{R}
$$

\footnotetext{
${ }^{12} \mathrm{Of}$ all the variables mentioned above, there is only information on regional gross value added $\left(V_{j}^{R}\right)$, as it is simply a sum of GDP by sector of the states conforming the region in question and that it is provided by INEGI. The remaining variables are estimated based on the detailed definitions, which are standard for these type of studies. See, for example, Ayala and Chapa (2013).
} 
Meanwhile, each of these components indicates the consumption of each sector " $\mathrm{j}$ " of the different sectors that provide inputs. Using this formula, we form the region's intermediate consumption matrix, which is one of the components of a RIOM. The sum of all elements yields total intermediate consumption of sector " $\mathrm{j}$ " of regional origin:

$$
Z_{j}^{R}=\sum_{i=1}^{n} Z_{i j}^{R}
$$

As mentioned in Section II, the Flegg method assumes that the techniques of national and regional production are the same. Under this assumption, at the regional level each sector " $\mathrm{j}$ " would be consuming intermediate goods with a value of:

$$
Z T_{j}^{R}=\sum_{i=1}^{n} a_{i j}^{N} * X_{j}^{R}
$$

Still, given that the Flegg method is applied to adjust regional production technique differences from what the region is supposed to consume, if it maintains national production techniques, minus what it, in fact, consumes given the adjusted production techniques that are obtained using the Flegg method, the total intermediate consumption of sector " $\mathrm{j}$ " stemming from the rest of the states $\left(Z R E_{j}\right)$ equals:

$$
Z R E_{j}=Z T_{j}^{R}-Z_{j}^{R}
$$

\subsection{Estimation of the Components of Final Demand and the Sector of Payments}

The RIOM is complemented by estimating, at the regional level, the components of the final demand $\left(C^{R}, I^{R}, G^{R}, E X P^{R}, M^{R}\right)^{13}$, as well as the components of the payment industry: value added $\left(V^{R}\right)$, taxes $\left(T_{j}^{R}\right)$ and imports $\left(M_{j}^{R}\right)$; along with the disaggregation of value added, that is taxes $\left(T S P N S_{j}^{R}\right)$, wages $\left(R E M_{j}^{R}\right)$ and the payment of capital $\left(E B O_{j}^{R}\right)$.

As regarding the components of regional final demand, for the case of private consumption and the regional government spending $\left(C^{R}\right.$ and $G^{R}$, respectively),

${ }^{13}$ The sum of all the elements should be equal to the amount of the final demand and that is why $C^{R}, I^{R}, G^{R}$ and $X^{R}$ are summed up. The difference between the final demand and the sum of the above mentioned elements is called "Exports to the rest of states". This last variable works as a way to absorb the error of using regional weights to obtain the components of the final demand. 
the national values of these variables are multiplied by the share of regional population in the national total; while regional investment $\left(I^{R}\right)$, that equals the gross capital formation plus the change in inventories, is obtained from multiplying the value of national investment by the share of regional GDP in the national total. ${ }^{14}$ For the case of $E X P^{R}$, state exports' data released by INEGI were used in order to obtain the corresponding regional values.

With respect to the components of the payment industry, $M^{R}$ was calculated as the average ratio of output to imports at the national level and the regional gross output, while $T_{j}^{R}$, which corresponds to taxes on goods, is estimated by applying the tax rate of the goods at the national level $\left(t_{j}^{N}\right)$ to the regional gross output $\left(X_{j}^{R}\right)$. Consequently, the item of regional wages $\left(R E M_{j}^{R}\right)$ is estimated multiplying the national figures by the share of regional wages in national wages (wage earners, self-employed, employers, and non-paid employees); while the tax on production $\left(T S P N S_{j}^{R}\right)$ is obtained by multiplying the payroll $\operatorname{tax}$ (ISN) by the sectorial share of wages in the region. The capital payment $\left(E B O_{j}^{R}\right)$ is obtained as the (residual) difference between $V^{R}$ and the rest of above-mentioned components. It should be noted that, insofar as the rest of components of $V^{R}$ have errors in the measurement, the analysis of the capital payment can fail to generate reliable results.

Once the aforementioned operations are carried out, we obtain the necessary information to construct RIOMs for the Mexican economy, along with estimates of value added at the regional level. ${ }^{15}$ Since there are four regions (Northern, North-Central, Central and Southern) according to the regionalization proposed in the "Reporte Sobre las Economias Regionales" published by Banco de México (see Figure 1), there are four matrices, one for each region.

\footnotetext{
${ }^{14}$ In the case of private consumption, it is possible to make approximations using the Household Income and Expenditure Survey (ENIGH, for its acronym in Spanish). However, it is well known that the survey is not representative at the state level, given the sample and the different spending patterns across regions. With respect to government spending, even though there is indeed information at the state level, there is no breakdown by sectors of origin, is the reason why it would be impossible to make the estimates corresponding to the item of the final demand. In view of the previously mentioned limitations, we proceed to estimate the final demand weighing private consumption and government spending by their participation in the population, while the variables of fixed capital gross formation and the change in inventories are weighed by the share of GDP.

${ }^{15}$ Appendix 2 presents all of the variables used for the estimation of RIOMs, including their respective definitions and sources.
} 
Figure 1

Regionalization

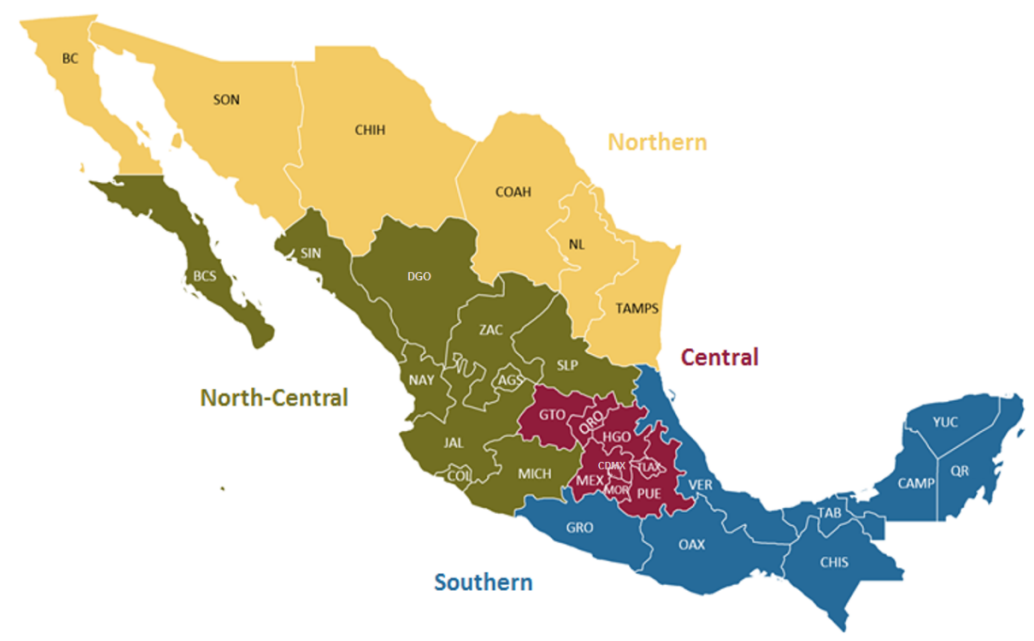

\begin{tabular}{|c|c|c|c|}
\hline Northern & North-Central & Central & Southern \\
\hline $\begin{array}{l}\text { Baja California } \\
\text { (BC) }\end{array}$ & Aguascalientes (AGS) & $\begin{array}{l}\text { Ciudad de México } \\
\text { (CDMX) }\end{array}$ & $\begin{array}{l}\text { Campeche } \\
\text { (CAMP) }\end{array}$ \\
\hline Chihuahua (CHIH) & $\begin{array}{l}\text { Baja California Sur } \\
\text { (BCS) }\end{array}$ & $\begin{array}{l}\text { Estado de México } \\
\text { (MEX) }\end{array}$ & Chiapas (CHIS) \\
\hline Coahuila (COAH) & Colima (COL) & Guanajuato (GTO) & Guerrero (GRO) \\
\hline Nuevo León (NL) & Durango (DGO) & Hidalgo (HGO) & Oaxaca (OAX) \\
\hline Sonora (SON) & Jalisco (JAL) & Morelos (MOR) & $\begin{array}{l}\text { Quintana Roo } \\
\text { (QR) }\end{array}$ \\
\hline \multirow{5}{*}{$\begin{array}{l}\text { Tamaulipas } \\
\text { (TAMPS) }\end{array}$} & Michoacán (MICH) & Puebla (PUE) & Tabasco (TAB) \\
\hline & Nayarit (NAY) & Querétaro (QRO) & Veracruz (VER) \\
\hline & San Luis Potosí (SLP) & Tlaxcala (TLAX) & Yucatán (YUC) \\
\hline & Sinaloa (SIN) & & \\
\hline & Zacatecas (ZAC) & & \\
\hline
\end{tabular}

Source: Banco de México.

\section{Impact on Regional Economic Activity of a Shock to Mexican Manufacturing Exports}

During the last decades the Mexican manufacturing sector has been the main pillar of Mexico's external sector, accounting today for almost 90 percent of total exports. In 2015, however, the dynamism it had been showing during the previous six years (average annual growth rate of 8 percent) came to a halt. More precisely, if we compare the value of annualized manufacturing exports 
in the third quarter of 2016 (USD 333,801 million) against the same figure of 2015 (USD 342,848 million), we obtain a contraction of USD 9,048 million.

Considering the above, this section applies input-output analysis to determine how an exogenous shock to Mexican manufacturing exports of a magnitude similar to the one indicated in the previous paragraph affects variables such as gross output, value added, and employment at the regional level.

\subsection{The Size of the Shock on the Manufacturing Sector and its Regional Distribution}

The exercise will consider, for simplicity, a shock on total manufacturing exports of USD 10,000 million, which represents 3.5 percent of total manufacturing exports from Mexico to the US in 2015. The regional distribution of the shock, in dollar terms, will be derived by multiplying the share of each region's manufacturing exports in total manufacturing exports, by the previously mentioned USD 10,000 million shock. Since official data indicate that the shares of regional manufacturing exports in total manufacturing exports are 61.3, 22.5, 13.0, and 3.2 percent for the Northern, Central, North-Central and the Southern regions, the regional shocks in dollar terms will amount to USD 6,130 million; USD 2,245 million; USD 1,300 million and USD 320 million, respectively (Table 1a). ${ }^{16}$

With an estimate of the four regional shocks at hand, the next step consists of distributing them within each region across the 12 manufacturing subsectors considered, to obtain the calculation of the regional input-output matrices. In each region, the shock is distributed in terms of the share of the subsectors' exports in total manufacturing exports, and is shown in Table 1b. Thus, we have four regional distributions of external shocks since the shares of regional manufacturing exports in total manufacturing exports differ across regions. This table is quite revealing as it shows that the impacts in the Northern, NorthCentral and Central regions concentrate in Machinery, Computer, Electrical and Electronic Product, and Transportation Equipment Manufacturing (subsectors 333-336), with shares of 76.6, 75.0 and 71.5 percent, respectively. In the South, on the other hand, the main subsectors to absorb the shock are Chemical (45.1 percent), Primary Metal (17.3 percent), and Food Manufacturing (13.8 percent).

${ }^{16}$ The data correspond to 2014 and were taken from INEGI. 
Table 1a

National Distribution of the Shock across Regions (\%)

\begin{tabular}{|c|c|c|c|c|c|}
\hline & Manufacturing Subsectors & Northern & $\begin{array}{l}\text { North- } \\
\text { Central }\end{array}$ & Central & Southern \\
\hline 311 & Food Manufacturing & 0.7 & 0.5 & 0.7 & 0.4 \\
\hline 312 & Beverage and Tobacco Product Manufacturing & 0.5 & 0.7 & 0.0 & 0.1 \\
\hline 313-314 & $\begin{array}{l}\text { Textile Mills and Textile Product Mills } \\
\text { Apparel Manufacturing, Leather and Allied Product }\end{array}$ & 0.2 & 0.0 & 0.2 & 0.0 \\
\hline $315-316$ & Manufacturing & 0.6 & 0.2 & 0.6 & 0.2 \\
\hline 321 & Wood Product Manufacturing & 0.0 & 0.0 & 0.0 & 0.0 \\
\hline $322-323$ & Paper Manufacturing & 0.2 & 0.0 & 0.1 & 0.0 \\
\hline $324-326$ & Oil and Chemical Manufacturing & 3.3 & 1.2 & 2.7 & 1.4 \\
\hline 327 & Nonmetallic Mineral Product Manufacturing & 0.6 & 0.1 & 0.4 & 0.0 \\
\hline $331-332$ & Primary Metal Manufacturing & 4.0 & 0.4 & 0.9 & 0.6 \\
\hline $333-336$ & $\begin{array}{l}\text { Machinery, Computer, Electrical and Electronic } \\
\text { Product, and Transportation Equipment Manufacturing }\end{array}$ & 47.0 & 9.8 & 16.1 & 0.2 \\
\hline 337 & Furniture and Related Product Manufacturing & 0.6 & 0.0 & 0.0 & 0.0 \\
\hline \multirow[t]{2}{*}{339} & Miscellaneous Manufacturing & 3.8 & 0.1 & 0.8 & 0.2 \\
\hline & Total & 61.3 & 13.0 & 22.5 & 3.2 \\
\hline
\end{tabular}

Table 1b

Relative Distribution of the Shock within Regions (\%)

\begin{tabular}{clcccc}
\hline & Manufacturing Subsectors & Northern & $\begin{array}{c}\text { North- } \\
\text { Central }\end{array}$ & Central & Southern \\
\hline \hline 311 & Food Manufacturing & 1.1 & 4.1 & 2.9 & 13.8 \\
312 & Beverage and Tobacco Product Manufacturing & 0.7 & 5.5 & 0.2 & 4.0 \\
$313-314$ & Textile Mills and Textile Product Mills & 0.2 & 0.2 & 0.9 & 0.5 \\
& Apparel Manufacturing, Leather and Allied Product & & & & \\
$315-316$ & Manufacturing & 0.9 & 1.4 & 2.6 & 5.8 \\
321 & Wood Product Manufacturing & 0.0 & 0.2 & 0.0 & 0.2 \\
$322-323$ & Paper Manufacturing & 0.4 & 0.3 & 0.5 & 0.2 \\
$324-326$ & Oil and Chemical Manufacturing & 5.4 & 9.0 & 12.0 & 45.1 \\
327 & Nonmetallic Mineral Product Manufacturing & 0.9 & 0.4 & 1.6 & 0.6 \\
$331-332$ & Primary Metal Manufacturing & 6.5 & 3.3 & 3.8 & 17.3 \\
$333-336$ & Machinery, Computer, Electrical and Electronic & 76.6 & 75.0 & 71.5 & 6.4 \\
337 & Product, and Transportation Equipment Manufacturing & 0.9 & 0.2 & 0.1 & 0.1 \\
339 & Furniture and Related Product Manufacturing & 0.1 & 0.4 & 3.7 & 6.0 \\
\hline & Miscellaneous Manufacturing & 100.0 & 100.0 & 100.0 & 100.0 \\
\hline \hline
\end{tabular}

Source: Own estimates with data from INEGI.

Figure 2 provides the shares of state manufacturing exports in national manufacturing exports, reinforcing the view of why external shocks may affect regions differently. As it can be seen, the North is the region which concentrates the largest shares of state manufacturing exports concerning national exports, and hence, is the most sensitive to external shocks. It is then followed by the Central, North-Central and Southern regions. 
Figure 2

Share of State Manufacturing Exports in National Manufacturing Exports (\%)

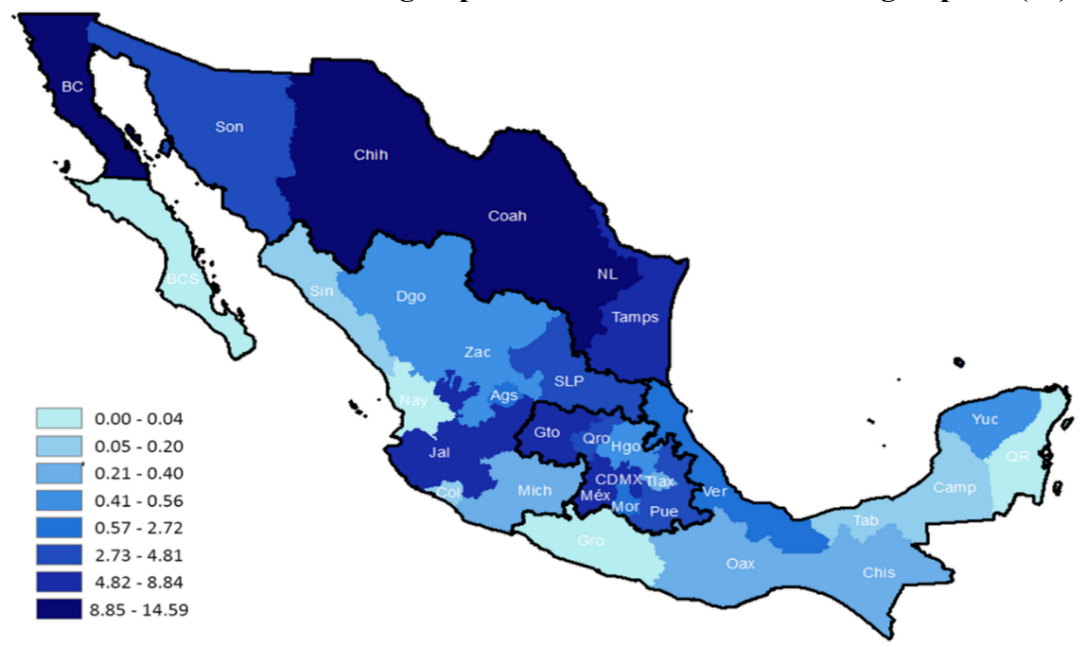

Source: Own estimates using INEGI data.

\subsection{Direct and Indirect Effects on Gross Output, Value Added and Employment}

Following the methodology outlined in subsections II and III, we now proceed to estimate direct and indirect effects on regional gross output, value added and employment of the shocks mentioned above. It is important to mention at this point that we will work with input-output matrices in which the "manufacturing sector" is divided in the 12 subsectors already shown in Tables $1 \mathrm{a}$ and $1 \mathrm{~b}$. Thus, in our analysis, the direct multiplier for the whole manufacturing sector within each region will be derived by adding the direct effects obtained across the 12 regional manufacturing subsectors. Clearly, given the complementarities among manufacturing subsectors, "indirect effects" are also expected to emerge among them. Hence, the total indirect multiplier will be obtained by adding the indirect effects from the manufacturing subsectors, to the indirect effects stemming from subsectors other than manufacturing. Tables 2-4 present these results, with gross output and value added expressed in MXN 2012 million; and employment expressed in number of workers. ${ }^{17}$

One feature that immediately stands out in Tables 2-4 has to do with large differences of total effects across regions. In particular, notice that the impacts

\footnotetext{
${ }^{17}$ Since the IOM refers to a 2012, the shocks were transformed from current dollars to 2012 pesos. This operation implied that the absolute shocks to gross output and value added are expressed in 2012 pesos.
} 
of the external shock on gross output, value added and employment in the North are, by far, the largest. This result, however, should not be considered a surprise as it was previously mentioned that this region concentrates 61.3 percent of total manufacturing exports, followed by the Central region with a distant 22.5 percent, the North-Central region with 13.0 percent, and, lastly, the Southern region, with a meager 3.2 percent of total manufacturing exports. Since the differences mentioned above imply that absolute impacts are very heterogeneous across regions, comparisons of absolute direct and indirect effects are of little value. Hence, in what follows we will be referring, first of all, to relative measures of the direct and indirect effects within each region (obtained by dividing the direct and indirect effects by the regional total effect); and, second, to the measures of changes at the regional level in the relevant variables (gross output, value added, and employment) which result from the shock, expressed as fractions of the 2012 absolute value of the corresponding variable.

\section{Gross Output}

Table 2 shows that the direct effects of the external shocks in manufacturing clearly dominate the indirect effects across all regions. The table also shows that the relative direct effect is significantly larger in the North (83.7 percent), followed by the North-Central region (79.8 percent), then by the Central region (79.5 percent), and lastly the Southern region (71 percent). Now, when taking into account the indirect effects of the manufacturing subsectors, the total effect on manufacturing (i.e., direct plus indirect effects of the manufacturing subsectors) goes up to 94 percent of the total effect in the North; up to 88 percent in the central regions; and 79 percent in the South. Notice also that manufacturing is the sector with the largest indirect effect in all regions, except the South. Another interesting pattern that emerges from Table 4, associated with the indirect effects of sectors other than manufacturing, is that they are concentrated in activities related with Commerce and Services (Administrative and Support Services; Professional, Scientific and Technical services; and Transportation). This supports the existence of a strong linkage between secondary and tertiary activities across the Mexican regions. 


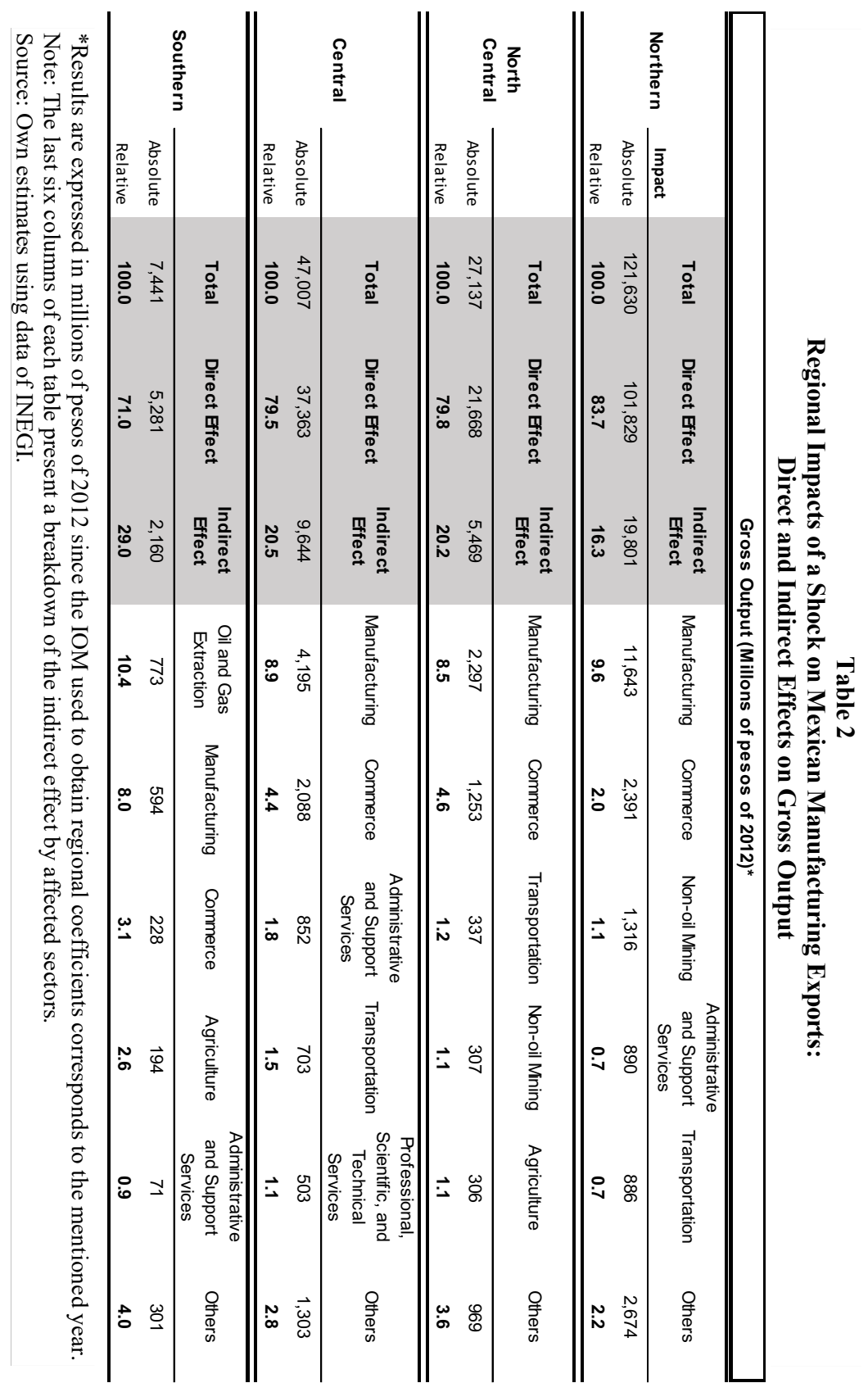


Figure 3 shows, in turn, the impacts of the export manufacturing shock on each state's gross output, as a fraction of their corresponding 2012 state gross output. The figure is useful to visualize the states that experience the largest changes in their gross output as a result of the external shock. As it can be readily seen, the pattern that emerges is one in which the largest effects are observed in the Northern states, followed by those of the Central, NorthCentral and Southern regions. This pattern makes sense as the Northern states are the ones more concentrated in export manufacturing activities, due to its economic integration with the United States; while those of the South show the lowest concentration in export manufacturing sectors (see, for instance, Table 1a).

\section{Figure 3}

Effect of a Shock on Manufacturing Exports on State's Gross Output (As a \% of State's Gross Output)

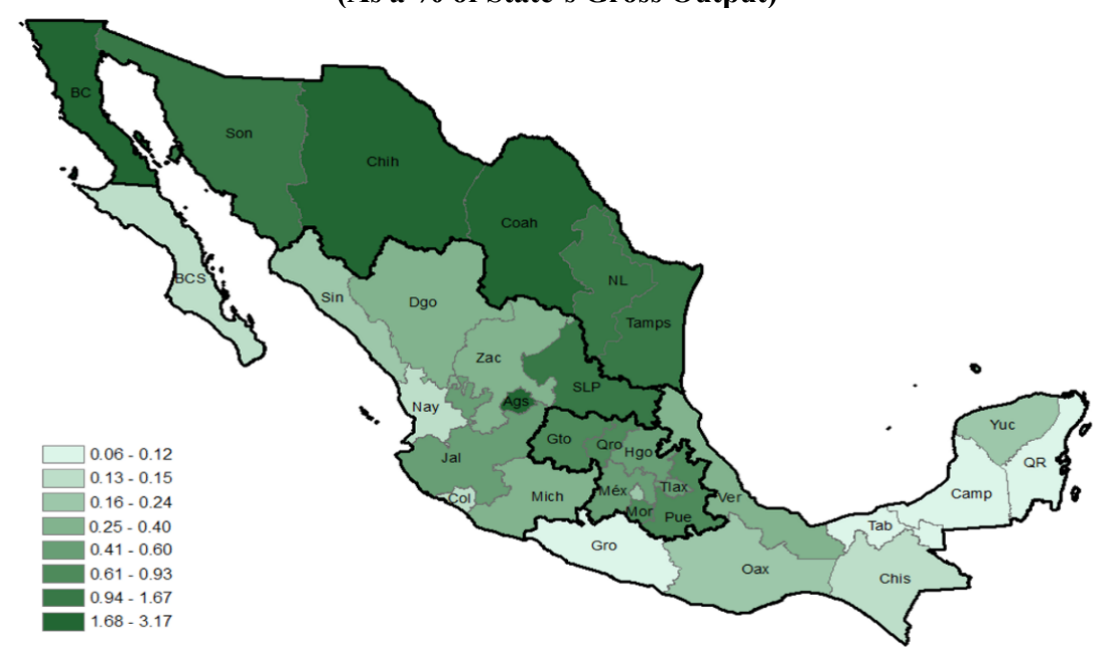

Source: Own estimates using INEGI data.

As a percentage of the initial regional shock, the indirect effect is the largest in the South, where it accounts for 40.9 percent of the shock, and the smallest in the North, where it accounts for 19.45 percent (Figure 4). This result in itself may be surprising, as the North is the most industrially developed and export oriented region in the country, while the South has a less developed industrial structure and a more inward oriented economy. 
Figure 4

Impact on Gross Output Relative to the Initial Regional Shock (\%) Total Impact Direct and Indirect Impacts
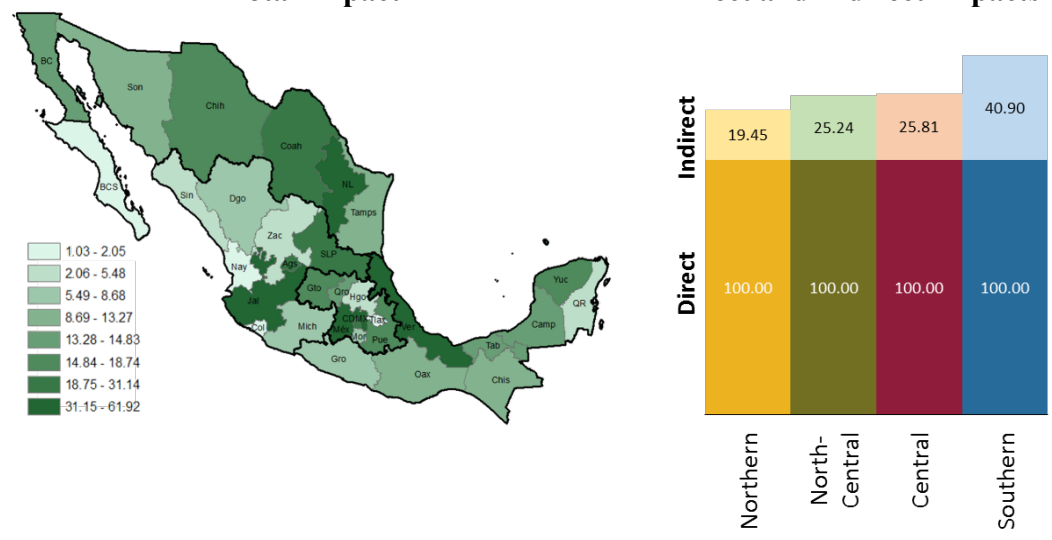

Source: Own estimates using INEGI data.

\section{Value Added}

In the case of value added, we find patterns roughly similar to those of gross output (Table 3). For instance, the direct effects are significantly larger than the indirect effects in the Northern, North-Central and Central regions. Another similar pattern is that the largest direct effect is again observed in the North (73.6 percent of the total impact), followed by those of the central regions (65.3 and 64.8 percent, respectively), and then the South (52 percent). A different pattern is that the sum of the direct and indirect effects of the manufacturing sector at the regional level is smaller than the sum of the same effects for gross output; however, indirect effects in value added are larger relative to those of gross output.

It is also worth mentioning that manufacturing, while being the sector registering the largest indirect effects for gross output, has been displaced by the commercial sector concerning value added in all regions, except the Northern region. As it was the case for gross output, Commerce and Services (specifically, in the Administrative and Support Services and Transportation) appear among the sectors with the largest indirect effects across all regions, particularly in the central regions. In the case of the South, Oil and Gas Extraction is the sector with the largest share in the indirect effect, which is to be expected given its relevance as an input provider for Chemical Manufacturing in that region.

The last row of each region's results presents the estimates of value added generated by the exogenous shock, as a fraction of regional GDP. These figures indicate that the North is, by far, the one experiencing the largest increase in 
GDP ( 1 percent), followed by the North-Central region ( 0.32 percent), then the Central region ( 0.26 percent) and, finally, the South ( 0.09 percent). Once again, this pattern could be related to the larger integration of the Northern regions to the U.S. economy. Also, while it is true that the absolute change in value added is greater in the Central region than in the North-Central one, it is also true that the latter generates more value added relative to regional GDP.

Another interesting pattern is observed in Figure 5, which shows the effect of increased manufacturing exports on each state's value added, expressed as fractions of each state's value added. Here, the darker (lighter) colored in a given state, the stronger (weaker) is the effect of the shock on that state's value added. As it is readily seen, the Northern states are the ones benefiting the most, and the Southern states the least.

Figure 6 shows, in turn, a map of the total impact on a state's value added as a percentage of the initial regional shock. In this case, the patterns are roughly the same as those for gross output, with Southern states displaying, on average, the largest direct (29.33 percent) and indirect (27.04 percent) impacts relative to the size of the initial regional shock, followed by states located in the Central regions, which show smaller relative direct (26 percent each) and indirect impacts (14 percent each), while the North displays, on average, the lowest direct ( 25.53 percent) and indirect ( 9.13 percent) impacts with respect to the initial shock.

\section{Employment}

The last effects analyzed are those on employment. In this case, Table 4 shows that the impact of the manufacturing exports shock has the strongest direct effect in the Northern and Southern regions (73.8 and 59.9 percent, respectively), followed by those displayed in the Central and North Central regions (55.6 and 54.9 percent, respectively). Table 6 also shows, as in the case of gross output and value added, that the indirect effects concentrate, in addition to Manufacturing, in Commerce and Services (Administrative and Support; Professional, Scientific, and Technical Services), which are recognized as labor intensive sectors.

Figure 7 presents the changes in each state's employment arising from the external shock, expressed as shares for each state's total employment. In this case, the figure shows that the relative impacts are, again, larger in the Northern states, followed by those of the central regions. Notice also that in some Southern states (specifically, Oaxaca, Guerrero, and Chiapas) the effects are larger than those of most states in other regions. 


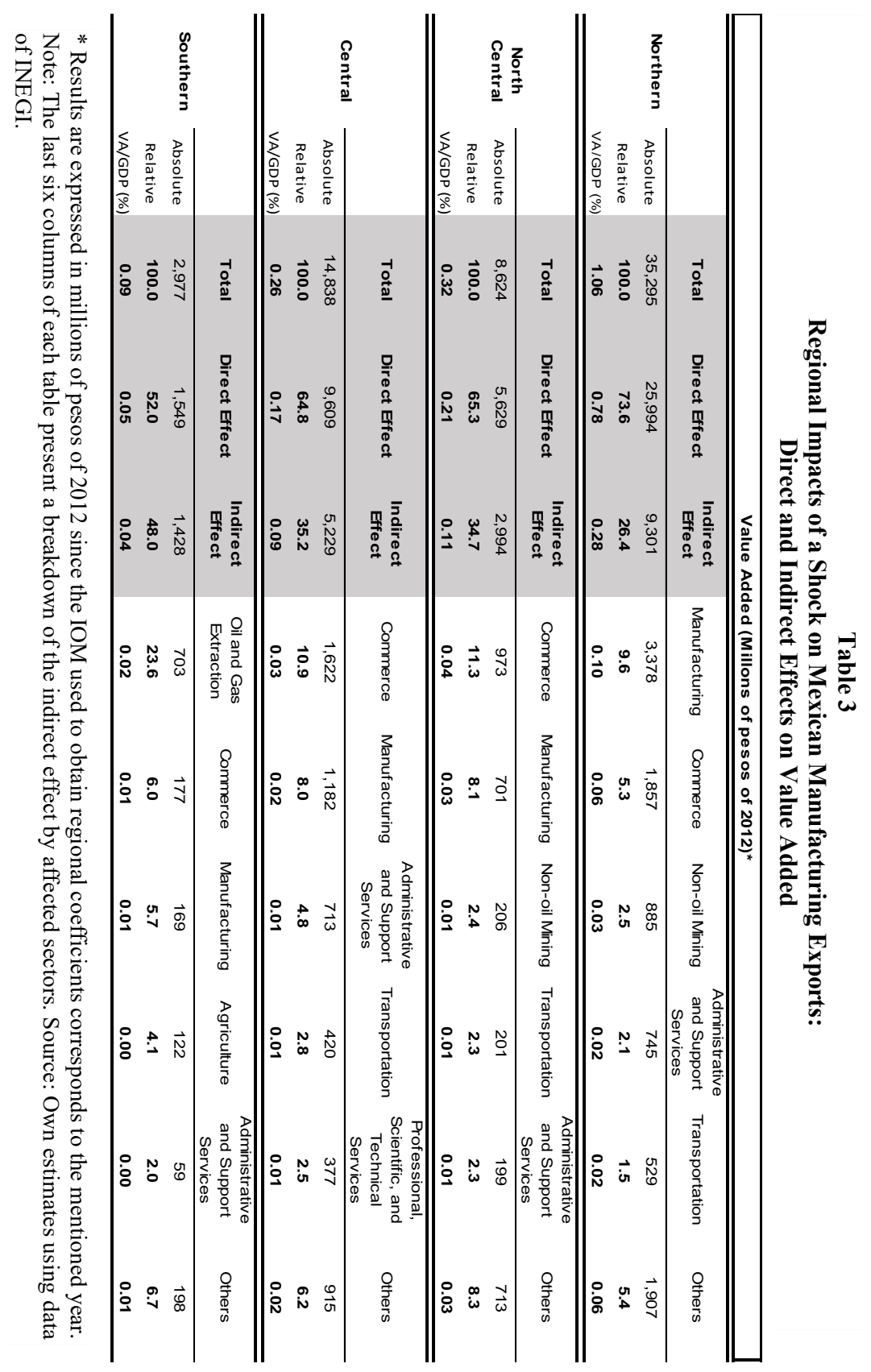


Figure 5

Effect of a Shock on Manufacturing Exports on State's Value Added (As a \% of State's Value Added)

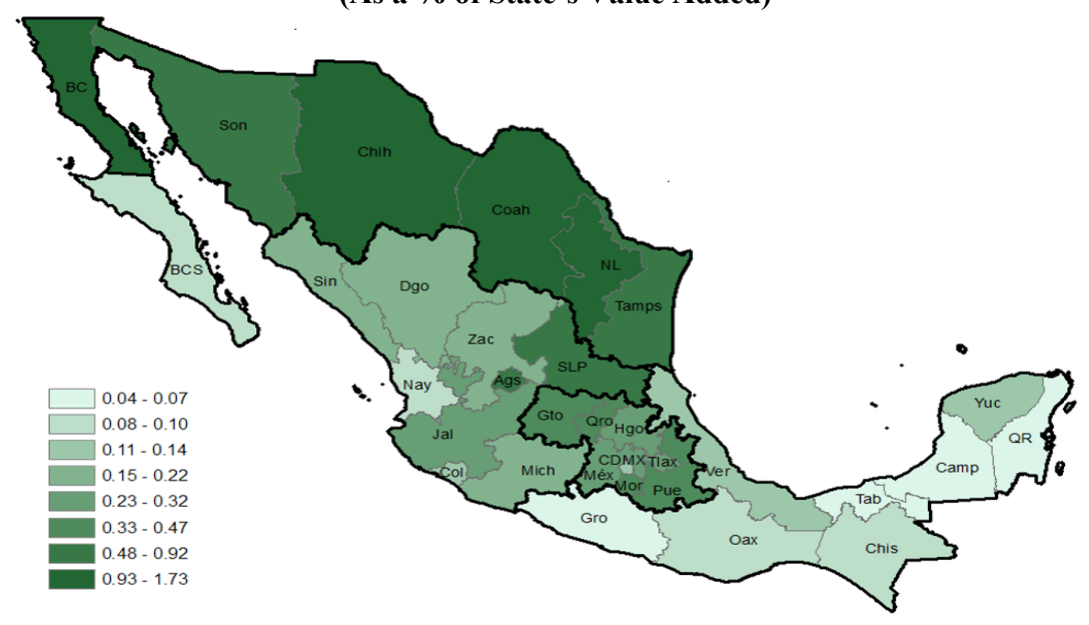

Source: Own estimates using INEGI data.

Figure 6

Impact on Value Added Relative to the Initial Regional Shock (\%) Total Impact Direct and Indirect Impacts
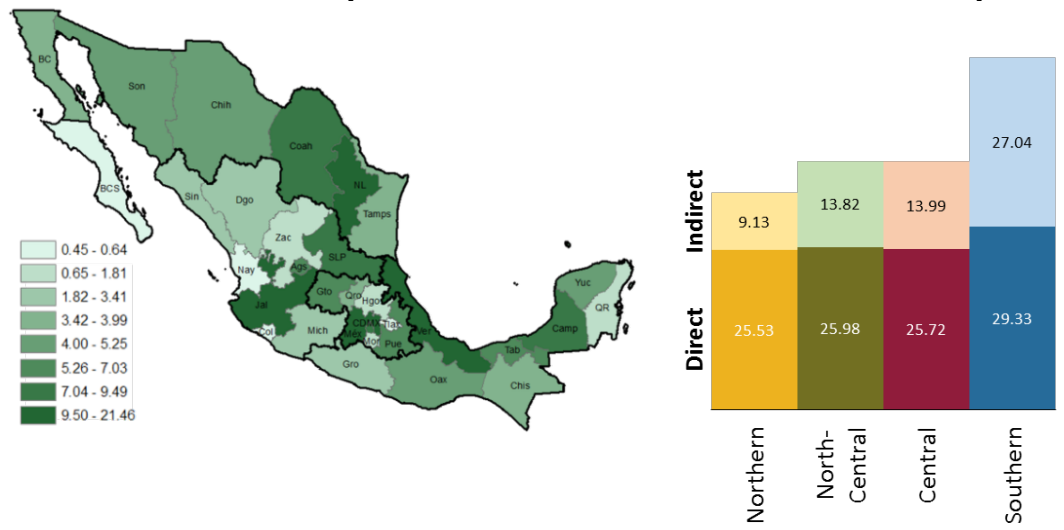

Source: Own estimates using INEGI data. 


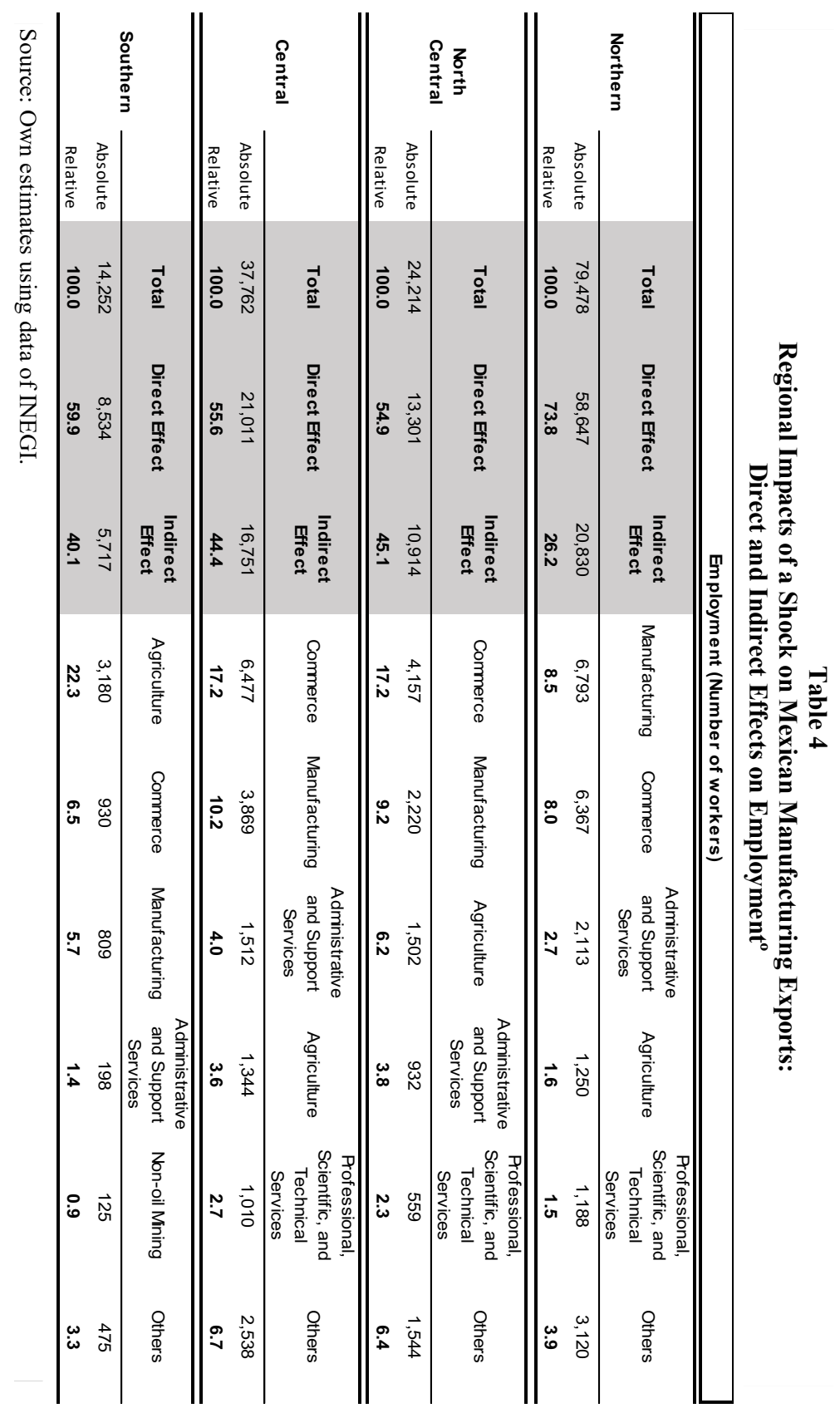


The result that the largest relative effects are observed in the Northern states as well as in the Southern states of Oaxaca, Guerrero, and Chiapas, deserving a few words, particularly when it has been the case that the South has been the region reporting the lowest direct effects in terms of gross output and value added. Regarding the results observed in the North, it can be argued that since this region possesses a large manufacturing sector, which is highly integrated to the U.S. economy, and then a strong positive external shock will significantly affect its economy, therefore propelling its employment levels. Some state economies of the South, on the opposite, are characterized by a relatively small manufacturing industry, but also by a small formal employment basis. As a result, it is plausible that an exogenous positive shock in manufacturing could bring about a relatively large increase in (formal) employment, mostly as a result of a base effect.

Figure 7

Effect of a Shock on Manufacturing Exports on State's Employment (As a \% of State's Employment)

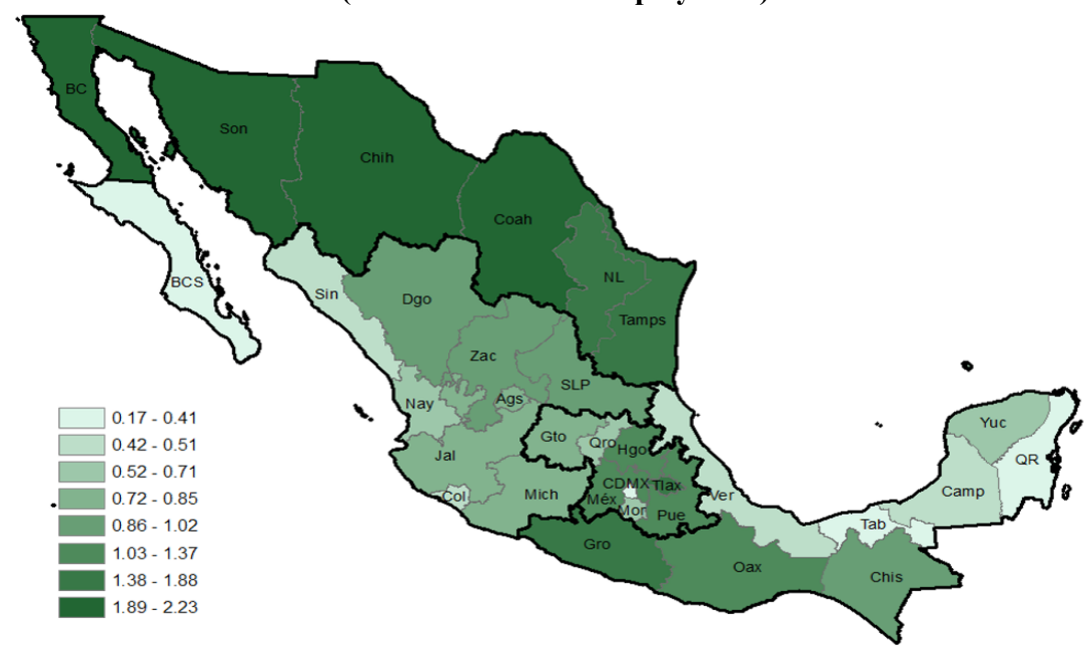

Source: Own estimates using data of INEGI.

Finally, Figure 8 presents indirect effects in each state's employment as the result from the shock on manufacturing exports, expressed as a fraction of each state's direct effect on employment. It can be seen that states located in the Central regional display, on average, the largest indirect effects on employment as a percentage of direct effects (79-82 percent), followed by Southern states (66.99 percent), and Northern states (35.52 percent).

Similar to gross output and value added, the RIOM analysis reveals substantial regional heterogeneity in the economic linkages across sectors in terms of 
employment, particularly between manufacturing and the rest of economic activities.

Figure 8

Indirect Effects as a \% of Direct Effects on Employment
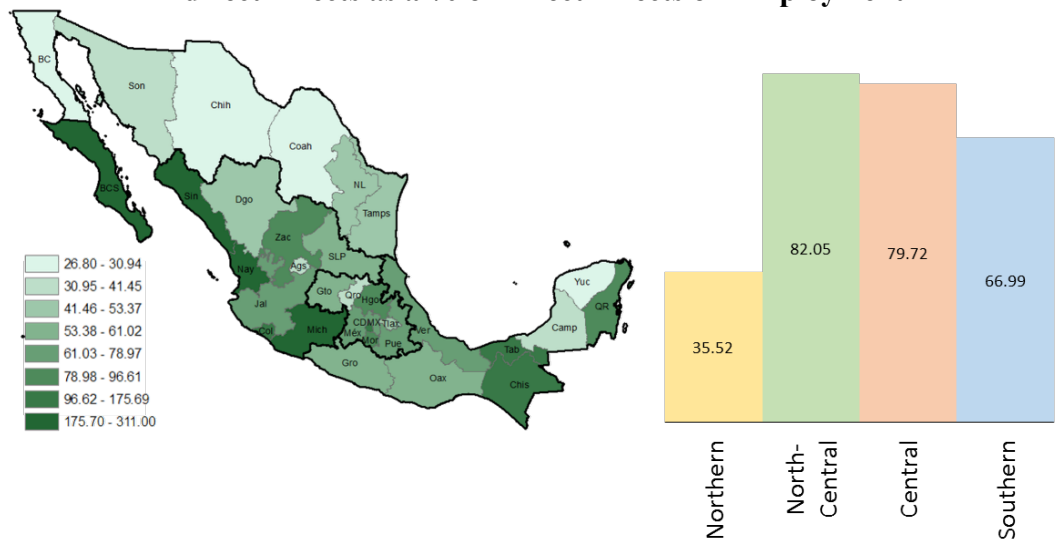

Source: Own estimates using INEGI data.

\section{Concluding Remarks}

A RIOM is a tool that allows us to estimate the impact on a variety of indicators of economic activity at sectorial and regional levels. In this work we employed RIOMs to measure the effects on gross output (XR), value added (VAR) and employment (ER) generated by a USD 10,000 million shock on Mexican manufacturing exports to each of the four regions in which Banco de Mexico divides the country.

The first interesting finding of the analysis is that the effect of the shock in the absolute values of the aforementioned variables are, overall, larger in the North, followed by the Central regions, and lastly the South. The same pattern holds when analyzing the relative impact among regions. Nevertheless, it was seen that the relative indirect effects at the regional level tend to increase for every sector when value added and employment are compared to gross output results. This implies that when gross output increases in any of the regions, there is a greater impact given that the multiplier effect is generated in value added and employment. The analysis also shows that the North is, by far, the region experiencing the greatest change in its value added relative to GDP, followed by the North-Central, the Central and the Southern regions.

Additionally, it was seen that within each region an important share of the indirect effects of the shock concentrates in manufacturing, suggesting possible complementarities inside the sector, particularly in the North; 
likewise, the results suggest a strong linkage between the manufacturing sector and tertiary activities, particularly Commerce and Services. This linkage is stronger in the central regions whose production is more oriented to the domestic market. In contrast, around half of the indirect impact of the shock in value added is concentrated in Oil and Gas Extraction in the South, which is explained by the importance of Chemical manufacturing in total exports of that region, as well as the demand for hydrocarbons in this sector.

The messages above are also implied in the patterns across states derived from the relative impacts of the external shock on the variables of interest (gross output, value added, and employment), with those relative impacts defined as the change in a state' $\mathrm{s}$ given variable arising from the external shock, as a fraction of that state's variable. In particular, it was seen that the Northern states are the ones reporting, overall, the largest relative effects, followed by those of the Central and North Central regions.

An interesting finding is that, once we normalize the impact, the multiplier effects tend to be larger in states not located in the North. Particularly, the South -the most inward oriented and least industrially developed regional economy- displays the largest indirect effects on gross output and value added, while the Central regions show the largest indirect effects on employment. This result, in turn, may be reflecting the fact that although the North is the region that benefits the most from exports, it is also the one that uses the highest proportion of intermediate inputs and therefore, its indirect effects tend to be lower than in the rest of the country. Thus, the RIOM analysis allows us to uncover the existence of substantial regional heterogeneity in indirect effects arising from a shock on manufacturing exports.

Finally, it must be taken into account that despite the usefulness of the RIOMs for the regional economic analysis, this approach has its limitations. Among them: (i) Fixed technical coefficients are assumed, excluding possible technological changes and factors substitution possibilities, even though this could happen in the short term and more likely in the medium or long terms. Hence, the need to frequently update RIOMs. (ii) The rigidity of the model (implicit in the fixed technical coefficients assumption) prevents us from reflecting on phenomena such as bottlenecks, increasing costs, etc. And, (iii) it is a very simple and restricted model that focuses only on the production side, and it does not explain why the relation between input and production follows a given pattern. As a result, the estimates provided here should be taken with caution, as they represent an initial effort to pinpoint the effects of an external shock across Mexican regional economies.

These limitations, however, open the road for future lines of work which could help refine the results presented in this paper. For instance, the methodology 
adopted here is not suited to pinpoint interregional effects. In other words, whenever a shock arises in any given region, the model does not allow us to identify how the sectorial reactions, which take place in the region suffering the shock, permeate separately to the other regions.

Also, the model employed in this paper assumes that the prices of intermediate and final goods are constant, an assumption which could be set aside in order to determine how overall prices may be affected by an exogenous shock.

\section{References}

[1] Acemoglu, D., Carvahlo, V., Ozdaglar, A., and A. Tahbaz-Salehi (2012). "The Network Origins of Aggregate Fluctuations." Econometrica. Vol. 80, No. 5, pp. 1977-2016

[2] Alvarado, J., Quiroga, M., and L. Torre (2017). "Una Estimación de Matrices Insumo-Producto Regionales para México y una Aplicación para el Sector Automotriz”. Banco de México, Documento de Investigación No. 2017-12.

[3] Autor, D., Dorn, D., and G. Hanson (2013). "The China Syndrome: Local Labor Market Effects of Import Competition in the United States." The American Economic Review, Vol. 103, No. 6, pp. 2121-2168(48).

[4] Ayala, E. and J. Chapa (2007). "Matriz Insumo Producto del Noreste de México." En Integración Económica Noreste de México-Texas: Diagnóstico y Prospectiva, Cap. IV. Programa para la Integración del Desarrollo Regional del Noreste y su Vinculación con Texas, Gobierno del Estado de Nuevo León, Fondo Editorial de Nuevo León.

[5] Ayala, E. and J. Chapa (2013). "Impacto Económico de las Heladas y del Financiamiento de la Resiembra en Sinaloa." Revista de Economía. Vol. 30, No. 81, pp. $11-55$.

[6] Bess, R. and Z. Ambargis (2011). "Input-Output Models for Impact Analysis: Suggestions for Practicioners Using the Regional Input-Output Modeling System (RIMS II) Multipliers." Paper presented at the 50th Southern Regional Science Association Conference. New Orleans, LA. March.

[7] Bonfiglio, A. and F. Chelli (2008). "Assessing the Behaviour of Non-Survey Methods for Constructing Regional Input-Output Tables through a Monte Carlo Simulation". Economic Systems Research, Vol. 20, No. 3, pp. 243 258.

[8] Caliendo, L., Parro, F, Rossi-Hansberg, E., and P. Sarte (2016). "The Impact of Regional and Sectoral Productivity Changes." Working paper.

[9] Callicó, J., González, E. and L. Sánchez (2000). "Matriz Insumo-Producto Regional. Colima, Jalisco, Michoacán y Nayarit.” Mimeo. Universidad de Guadalajara. Guadalajara, Jalisco.

[10] Chapa, J. and E. Rangel (2010). "Análisis de la Estructura Productiva y de IngresoGasto para el Estado de Nuevo León 2004.” EconoQuantum. Vol. 6. No. 2, pp. 55-79.

[11] Chiquiar, D. (2005). "Why Mexico's Regional Income Convergence Broke Down." Journal of Development Economics. Vol. 77, No. 1, pp. 257 - 275. 
[12] Chiquiar, D., Covarrubias, C., and A. Salcedo (2014). "Labor Market Consequences of Trade Openness and Competition in Foreign Markets." Working paper.

[13] Cosar, A. and P. Fajgelbaum (2016). "Internal Geography, International Trade, and Regional Specialization.” American Economic Journal: Microeconomics. Vol. 8, No. 1, pp. 24-56.

[14] David, H., Dorn, D., and G. Hanson (2013). "The China Syndrome: Local Market Effects of Import Competition in the United States." American Economic Review. Vol. 103, No. 6, pp. $2121-2168$.

[15] Dávila, A. (2002). "Matriz de Insumo-Producto de la Economía de Coahuila e Identificación de sus Flujos Intersectoriales más Importantes.” Economía Mexicana. Nueva Época. Vol. XI, No. 1, primer semestre, pp. 79-162.

[16] Dávila, A. (2015). “¿Por qué y Cómo Elaborar Modelos Interregionales de Insumo Producto Mediante la Aplicación de Métodos Indirectos de Estimación?”. En Modelos Interregionales de Insumo-Producto de la Economía Mexicana, A. Dávila (coordinador), Editorial M.A. Porrúa, pp. 7 - 26.

[17] Flegg A., Webber, C., and M. Elliot (1995) "On the Appropriate Use of Location Quotients in Generating Regional Input-Output Tables”. Regional Studies, Vol. 29, No. 6, pp. $547-561$.

[18] Flegg, A. and T. Tohmo (2013). "Regional Input-Output Tables and the FLQ Formula: A Case Study of Finland”. Regional Studies, Vol. 47, No. 5, pp. 703 $-721$.

[19] Flegg A. and C. Webber (2000) "Regional Size, Regional Specialization and the FLQ Formula”. Regional Studies, Vol. 34, No. 6, pp. 563 - 569.

[20] Foerster, A., Sarte, P., and M. Watson (2011). "Sectoral versus Aggregate Shocks: A Structural Factor Analysis of Industrial Production." Journal of Political Economy. Vol. 119, No. 1, pp. $1-38$.

[21] Fuentes, N. (2005). "Construcción de una Matriz Regional de Insumo-Producto." Problemas del Desarrollo. Revista Latinoamericana de Economía. Vol. 36, No. 140, enero-marzo, pp. 90-112.

[22] INEGI (2014). Sistema de Cuentas Nacionales de México. Tablas de Origen Destino de la Formación Bruta de Capital Fijo 2003 - 2012, Base 2008. Fuentes y Metodologías.

[23] Isard, W. (1951). "Interregional and Regional Input-Output Analysis: A Model of a Space Economy". Review of Economics and Statistics, Vol. 33, pp. 318 328.

[24] Lahr, M. (1993). "A Review of Literature Supporting the Hybrid Approach to Constructing Regional Input-Output Models". Economic Systems Research, Vol. 5, pp. $277-293$.

[25] Leontief, W. (1953). Studies in the Structure of the American Economy. Oxford University Press.

[26] Leontief, W. (1986). Input-Output Economics. Oxford University Press.

[27] Lynch, R. (1986). “An Assessment of the RAS Method for Updating Input-Output Tables" in Readings in Input-Output Analysis, Oxford University Press, pp. $271-284$.

[28] Miller, R. and P. Blair (2009). Input-Output Analysis. Foundations and Extensions. Cambridge University Press. 2nd Edition. Cambridge. 
[29] Rodríguez, E. (1995). "La Construcción de una Matriz de Contabilidad Social (o de Insumo-Producto Extendida) para Nuevo León.” Revista Ensayos, Vol. XIV, No. 1, pp. 107-135.

[30] Round, J. (1983). "Non-survey techniques: A Critical Review of the Theory and the Evidence”. International Regional Science Review, Vol. 8, No. 3, pp. 189 -212 .

[31] Sobarzo, H. (2011). "Modelo de Insumo-Producto en Formato de Matriz de Contabilidad Social. Estimación de Multiplicadores e Impactos para México, 2003." Economía Mexicana, Vol. 20, No. 2, pp. 237 - 280.

[32] Toh, M. (1998). "The RAS Approach in Updating Input-Output Matrices: An Instrumental Variable Interpretation and Analysis of Structural Change". Economic Systems Research, Vol. 10, No. 1, pp. 63 - 78.

[33] Tohmo, T. (2004). "New Developments in the Use of Location Quotients to Estimate Regional Input-Output Coefficients and Multipliers". Regional Studies, Vol. 38, No. 1, pp. 43 - 54.

[34] Trinh, B. and N. Viet-Phong (2013). "A Short Note on the RAS Method". Advances in Management \& Applied Economics, Vol. 3, No.4, pp. 133 - 137.

[35] Valdez, Y. (2004). "Matriz de Insumo-Producto para Tamaulipas: Análisis de Multiplicadores y Encadenamientos." Tesis de Maestría en Economía Aplicada. El Colegio de la Frontera Norte. Tijuana, Baja California. 


\section{Appendix 1}

Sectors of the North American Industry Classification System (NAICS)

\begin{tabular}{cl}
\hline No. & \multicolumn{1}{c}{ Sectors in accordance with the NAICS classification } \\
\hline 1 & Agriculture \\
3 & Oil and gas extraction \\
4 & Mining (except oil) \\
& Slectric power generation, transmission and distribution; and water and gas \\
5 & Construction \\
6 & Food manufacturing \\
7 & Beverage and tobacco product manufacturing \\
8 & Textile product mills, fabric finishings; textile mills, except apparel \\
9 & Apparel manufacturing; leather and hide tanning and finishing; and leather \\
& and allied products manufacturing \\
10 & Wood product manufacturing \\
11 & Paper manufacturing \\
12 & Chemical manufacturing \\
13 & Nonmetallic mineral product manufacturing \\
14 & Primary metal manufacturing \\
15 & Machinery manufacturing; computer, communications, measuring \\
& instruments and other equipment manufacturing, electronic components \\
& manufacturing; electrical equipment, appliance, and component \\
16 & manufacturing; transportation equipment manufacturing \\
17 & Furniture and related product manufacturing \\
18 & Trade \\
19 & Transport, postal service and warehousing \\
20 & Information \\
21 & Finance \\
23 & Real estate and rental and leasing \\
25 & Professional, scientific and technical services \\
26 & Management of companies and enterprise \\
& Edministrative and support services \\
& Educational services \\
& Entertaine and social assistance \\
& Accommodation and food services \\
&
\end{tabular}


Appendix 2

Variables Used for Input-Output Matrix

\begin{tabular}{|c|c|c|}
\hline Variable: & Definition: & Sources \\
\hline$a_{i j}^{N}$ & $\begin{array}{l}\text { National technical coefficients: input quantity "i" required to } \\
\text { obtain a unit of final good "j" at the national level }\end{array}$ & $\begin{array}{l}\text { National IOM } \\
\text { (INEGI) }\end{array}$ \\
\hline$a_{i j}^{R}$ & $\begin{array}{l}\text { Regional technical coefficients: input quantity "i" required to } \\
\text { obtain a unit of final good " } \mathrm{j} \text { ” at the regional level }\end{array}$ & INEGI \\
\hline$x_{j}^{R}$ & Regional gross output by sector $\mathrm{j}$ & $\begin{array}{l}\text { GDP (INEGI), } \\
\text { National IOM } \\
\text { (INEGI) }\end{array}$ \\
\hline$Z_{i j}^{R}$ & Regional intermediate demand & INEGI \\
\hline$Z_{j}^{R}$ & Regional intermediate consumption $=\sum \mathrm{Z}_{\mathrm{ij}}^{\mathrm{R}}$ & Regional IOM \\
\hline $\mathrm{ZRE}_{\mathrm{j}}^{\mathrm{R}}$ & Regional intermediate consumption of other states & Residual \\
\hline $\mathrm{ZT}_{\mathrm{j}}^{\mathrm{R}}$ & $\begin{array}{c}\text { Total intermediate consumption }=\text { Regional intermediate } \\
\text { consumption }(\mathrm{Z})+\text { Regional intermediate consumption of other } \\
\text { states (ZRE) }\end{array}$ & Regional IOM \\
\hline $\mathrm{m}_{\mathrm{j}}^{\mathrm{N}}$ & $\begin{array}{c}\text { (Total imports at the national level of sector “j”) / (National } \\
\text { Gross Output) }\end{array}$ & INEGI \\
\hline$M_{j}^{R}$ & Total regional imports by sector $\mathrm{j}$ & $\begin{array}{l}\text { National IOM } \\
\text { (INEGI) }\end{array}$ \\
\hline$t_{j}^{N}$ & $\begin{array}{c}\text { (Taxes on goods and services net of subsidies at the national } \\
\text { level) / (National Gross Output) }\end{array}$ & $\begin{array}{l}\text { National IOM } \\
\text { (INEGI) }\end{array}$ \\
\hline $\mathrm{T}_{\mathrm{j}}^{\mathrm{R}}$ & $\begin{array}{c}\text { Taxes on goods and services net of subsidies at the regional } \\
\text { level of sector "j" }\end{array}$ & $\begin{array}{l}\text { National IOM } \\
\text { (INEGI) }\end{array}$ \\
\hline$V_{j}^{R}$ & Regional gross value added & GDP (INEGI) \\
\hline $\mathrm{REM}_{\mathrm{j}}^{\mathrm{N}}$ & Total national wages of sector " $\mathrm{j}$ " & $\begin{array}{l}\text { National IOM } \\
\text { (INEGI) }\end{array}$ \\
\hline$\alpha$ & Regional participation in national wages & INEGI \\
\hline $\mathrm{REM}_{\mathrm{j}}^{\mathrm{R}}$ & Total regional wages by economic sector $=\alpha * \mathrm{REM}_{\mathrm{j}}^{\mathrm{N}}$ & $\begin{array}{l}\text { National IOM } \\
\text { (INEGI) }\end{array}$ \\
\hline$\beta$ & $\mathrm{REM}_{\mathrm{j}}^{\mathrm{R}} / \sum_{\mathrm{j}=1}^{\mathrm{n}} \mathrm{REM}_{\mathrm{j}}^{\mathrm{R}}$ & INEGI \\
\hline $\mathrm{ISN}^{\mathrm{R}}$ & Payroll tax collection at the regional level & INEGI \\
\hline TSPNS $_{j}^{R}$ & $\begin{array}{l}\text { Taxes on production net of subsidies by sector } \mathrm{j} \text { at the regional } \\
\qquad \beta^{*} \mathrm{ISN}^{\mathrm{R}}\end{array}$ & INEGI \\
\hline $\mathrm{EBO}_{i}^{\mathrm{R}}$ & Gross Operating Surplus $=V_{j}{ }^{R}-R_{E M j}{ }^{R}-T S P N S j R$ & Residual \\
\hline $\mathrm{F}_{\mathrm{i}}^{\mathrm{R}}$ & Regional final demand & Regional IOM \\
\hline$\gamma$ & $\begin{array}{c}\text { Share of regional population in national population } \\
\text { (Population / Population }{ }^{N} \text { ) }\end{array}$ & CONAPO \\
\hline$\Theta$ & $\begin{array}{l}\text { Share of Regional GDP in National GDP: } \\
\qquad=\left(\text { GDP }^{\mathrm{N}} / \mathrm{GDP}\right)\end{array}$ & INEGI \\
\hline $\mathrm{C}_{\mathrm{i}}^{\mathrm{N}}$ & National private consumption for each sector i & $\begin{array}{l}\text { National IOM } \\
\text { (INEGI) }\end{array}$ \\
\hline $\mathrm{C}_{\mathrm{i}}^{\mathrm{R}}$ & Regional private consumption for each sector $\mathrm{i}=(\gamma)\left(\mathrm{C}_{\mathrm{i}}^{\mathrm{N}}\right)$ & INEGI \\
\hline$G_{i}^{N}$ & National public spending for each sector $i$ & $\begin{array}{l}\text { National IOM } \\
\text { (INEGI) }\end{array}$ \\
\hline$G_{i}^{R}$ & Regional public spending for each sector $\mathrm{i}=(\gamma)\left(\mathrm{G}_{\mathrm{i}}^{\mathrm{N}}\right)$ & INEGI \\
\hline$I_{i}^{N}$ & National gross fixed capital formation of sector "i" & INEGI \\
\hline$I_{i}^{R}$ & $\begin{array}{l}\text { Regional gross fixed capital formation of sector: } \\
\qquad \mathrm{i}=\Theta^{*} \mathrm{Ii}^{\mathrm{N}}\end{array}$ & INEGI \\
\hline $\operatorname{EXP}_{i}^{R}$ & International exports by sector $i$ at the regional level & INEGI \\
\hline $\operatorname{EXPRE}_{i}^{R}$ & $\begin{array}{l}\text { Net exports of the region to other states by sector i: } \mathrm{F}_{\mathrm{i}}^{\mathrm{R}}-\left(\mathrm{C}_{\mathrm{i}}^{\mathrm{R}}+\right. \\
\left.\qquad \mathrm{G}_{\mathrm{i}}^{\mathrm{R}}+\mathrm{I}^{\mathrm{R}}+\mathrm{VE}_{\mathrm{i}}^{\mathrm{R}}+\mathrm{EXP}_{\mathrm{i}}^{\mathrm{R}}\right)\end{array}$ & Residual \\
\hline
\end{tabular}

